\title{
Reactions of Juvenile Delinquents to "Justified" and "Less Justified" Movie Violence*
}

\author{
LEONARD BERKOWITZ \\ Vilas Research Professor in Psychology, University of Wisconsin \\ Ph.D. (Psychology), 1951, University of Michigan
}

\section{Ross D. Parke}

Chief, Social Development Section, Fels Research Institute, Yellow Springs, Ohio Ph.D. (Psychology), 1963, University of Waterloo

\author{
Jacques-Philippe Leyens
}

Faculté de Psychologie, Université de Louvain

Ph.D. (Psychology), 1969, Université de Louvain

\section{STEPhen G. West}

Assistant Professor of Psychology, Florida State University

Ph.D. (Psychology) , 1972, University of Texas

In order to determine whether juvenile delinquents would respond to the sight of someone being beaten up the same way as previously studied university students, two-thirds of the institutionalized delinquents in the sample watched a brief filmed prize fight after having been insulted or treated in a neutral fashion by the experimenter's confederate. A story summary given to the subjects depicted the defeated movie character as either a callous exploiter of other persons or as a more sympathetic individual. Immediately after the film the insulted delinquents shown the exploiter being beaten administered stronger electric shocks to the confederate than a no-movie control group and somewhat more than other provoked subjects seeing the sympathetic character being hurt. Like the university students, the delinquents had apparently regarded the exploiter's beating as "justified" aggression; and this interpretation temporarily legitimated their own attacks upon their tormentor.

\footnotetext{
- The research reported in this paper was supported by grant MH17955 from the Center for the Study of Crime and Delinquency, the National Institute of Mental Health, to the first two authors. We are grateful to Lloyd Mixdorf and Roland Hershman, Assistant Superintendent and Superintendent,
}

respectively, of the Wisconsin School for Boys at Wales, for their fine cooperation in the conduct of this research and to Thomas Bassett, James Cowden, and Asher Pacht for their general assistance throughout our research programs. 
T ARIOUs INVESTIGATORs have asked whether juvenile delinquents as a group hold attitudes and values that distinguish them from nondelinquents. ${ }^{1}$ The researchers have generally pursued this question by direct measurement of the attitudes and values presumably differentiating the delinquent and nondelinquent populations. The present paper offers a fairly novel approach to this problem. We here compare the aggressive reactions of delinquents and nondelinquents to filmed violence, inquiring whether they respond in the same way to the sight of someone being beaten up. If delinquents, behave differently from other groups after watching movie aggression, this difference could well stem from their unique attitudes toward violence.

Experiments with middle-class university students have repeatedly found that the observer's response to filmed violence depends in part on his judgment of the propriety of the depicted aggression. ${ }^{2}$ If he is angry at the time the movie is presented and then has

1. For example, James Short, Jr., and Fred L. Strodtbeck, Group Processes and Gang Delinquency (Chicago: University of Chicago Press, 1965).

2. L. Berkowitz and E. Rawlings, "Effects of Film Violence on Inhibitions against Subsequent Aggression," Journal of Abnormal and Social Psychology, 66:405-412, 1963; L. Berkowitz, R. Corwin, and M. Heironimus, "Film Violence and Subsequent Aggressive Tendencies," Public Opinion Quarterly, 27:217-229, 1963; L. Berkowitz, "Some Aspects of Observed Aggression," Journal of Personality and Social Psychology, 2:359-369, 1965; L. Berkowitz and R. G. Geen, "Stimulus Qualities of the Target of Aggression," Journal of Personality and Social Psychology, 5:364-368, 1967; J. L. Hoyt, "Effect of Media Violence 'Justification' on Aggression," Journal of Broadcasting, 14:455-464, 1970; T. P. Meyer, "Effects of Viewing Justified and Unjustified Real Film Violence on Aggressive Behavior," Journal of Personality and Social Psychology, 23:21-29. 1972. an opportunity to attack his tormentor at the end of the film, he is apt to show the strongest aggression if he thought the witnessed violence was justified. It's as if the warranted or "proper" aggression on the screen had temporarily legitimated the observer's own aggressive inclinations.

In this research the filmed violence was usually defined as justified or not by varying the information given the subjects about the defeated character. All of the experiments except one ${ }^{3}$ used an excerpt from the movie Champion, in which the protagonist, a champion prize fighter, took a bad beating during a title bout. A brief synopsis provided before the movie started (supposedly so that the subjects would better understand the scene) portrayed the champion in either a sympathetic or a less sympathetic manner. In the latter case he was described as a person who had frequently and shamelessly exploited other people in his rise to the championship. The college students, therefore, regarded the beating he received in the fight as justified punishment for his past misdeeds. ${ }^{4}$ In the opposing condition, by contrast, the story summary depicted him more favorably; and, as a consequence, the students viewed his defeat as less justified aggression.

Our question here is whether juvenile delinquents would respond in the same way as the university students employed in these earlier experiments. One could argue either way. Findings obtained by some investigators suggest that there would be differences. Whether or not there is a separate, delinquent subculture, various authorities contend that delinquents

3. Meyer, supra note 2.

4. Ibid. 
generally value being hard, tough, and able to outsmart others. ${ }^{5}$ Consistent with this orientation, delinquent boys are especially likely to think of social relationships as hostile interactions ${ }^{6}$ and are greatly concerned with their ability to exert power over their peers. ${ }^{7}$ They are also likely to be exploitative, believing that they have the right to take advantage of "suckers." 8 All in all, in the words of some of these researchers, the delinquent boy seems to be "sensitive to and aware of many ingenious techniques for manipulating others. Rather than withdrawing from others, he appears more oriented toward aggressively taking, demanding, and doing." 9 We might expect from all this that delinquents would not be unsympathetic to the tough, hard-hearted exploiteras the fight loser, the champion, is described in the supposedly justified film aggression condition. They might even be attracted to him. As a consequence, the beating the champion receives in the movie would appear relatively unwarranted; and the delinquents should, therefore, be less willing to act aggressively themselves immediately afterwards. Following this reasoning, then, the difference between the "justified" and "less justified" film aggression conditions found in the earlier studies with university

5. P. Lerman, "Individual Values, Peer Values, and Subcultural Delinquency," $A$ merican Sociological Review, 33:219-235, 1968.

6. M. F. Shore, J. L. Massimo, and J. K. Moran, "Some Cognitive Dimensions of Interpersonal Behavior in Adolescent Delinquent Boys," Journal of Research in Crime and Delinquency, 4:243-247, 1967.

7. M. Gold, "Juvenile Delinquency as a Symptom of Alienation," Journal of Social Issues, 25:121-135, 1969.

8. T. Hirschi, Causes of Delinquency (Berkeley: University of California Press, 1971), p. 202.

9. Shore, supra note 6, p. 247. students should be minimized or even reversed in the present delinquent population.

However, we should be careful not to exaggerate the uniqueness of the values held by juvenile delinquents. Several investigations have shown that these youngsters have many of the same beliefs and values as their middle-class, normal counterparts. ${ }^{10}$ Much like university students, they too could be affronted by the fight loser's callous exploitation of other people and would, therefore, also regard his beating as entirely proper and deserved. To the extent that this is the case, angry delinquent boys viewing the presumably justified film aggression should be more aggressive soon afterwards than other delinquents seeing the less warranted violence.

Another problem has to do with the validity of the laboratory aggression measure. The subjects in this type of research typically administer electric shocks to a peer as their judgment of the peer's performance on an assigned task. Does the intensity of the punishment reflect aggression or merely some passive compliance with the experimenter's implied "demands"? Several observations suggest that the severity of the shocks the subjects deliver in this kind of situation is a manifestation of their habitual aggressiveness. In one study using third-grade school children, ${ }^{11}$ as an example, the youngsters who were most punitive in the laboratory situation were also generally rated by their classmates as being highly aggressive outside of the lab-

10. Lerman, supra note 5; Short and Strodtbeck, op. cit. supra note 1 .

11. J. F. Williams et al,, "Relation of PeerRelated Aggression to Aggressive Responses Elicited in an Experimental Situation," Child Development, 38:181-189, 1967. 
oratory. Similarly, in another experiment ${ }^{12}$ counselor ratings of the aggressiveness of high school students in an Upward Bound program were positively correlated with the shock intensities the student administered in punishing someone else. Available data enable us to determine whether the laboratory punitiveness displayed by the present sample is also related to the boys' characteristic aggressiveness in other settings.

\section{Method}

\section{Subjects}

Four different cottages from the Wales School for Boys in Wisconsin participated in the experiment, two in the fall of 1969 and two the next spring. Two experimenters and one assistant ran the study in each time period, but these were different people in the fall and spring sessions. The subjects were assigned randomly to the conditions. However, only half (44) of the 88 boys in these four cottages constitute the present sample. Since the experiment was to be the start of a long-term project, we had taken this opportunity to investigate another laboratory aggression measure -punching a bag and thereby supposedly transmitting a punch mechanically to someone at the other end of the apparatus. Each of the 88 subjects used both procedures, the electric shocks and the punching bags, with half of the youngsters giving shocks first and the others punching first. Although the punch data yielded the same general pattern as the shock scores, the results were not quite as clear with the former measure, prob-

12. K. M. Shemberg, D. B. Leventhal, and L. Allman, "Aggression Machine Performance and Rated Aggression," Journal of Experimental Research in Personality, 3:117-119, 1968. ably because the boys had to exert much more effort in delivering their punches. We, therefore, decided to exclude those subjects who punched first. The present shock measure is fairly similar to the measure employed in the University research.

The median age of the 44 boys in the final sample was 16 years. Fiftyseven per cent were white, with all but one of the rest black. Placing their fathers' occupational statuses on a five-point continuum ranging from professional (one) to unskilled (five), their mean status background was 3.6, close to the "semiskilled" level. This was also the modal level.

\section{Procedure}

The subjects were told by their cottage counselors that they would have to participate in a project for the university involving new teaching machines and methods. As reward for their participation each boy was paid $50 \phi$. Both times the experiment took place during a prolonged weekend.

The setting of the experiment included three adjacent classrooms, A, $B$, and C. The subject was met in room $\mathrm{A}$ by the experimenter, who introduced him to another boy (actually a high school student serving as the experimenter's confederate) who would help with the project. The experimenter told the subject that he and his partner would help him try some new methods in teaching and learning. The subject then sat in front of his teaching machine while the other boy was sent to room $\mathrm{C}$ and the experimenter went to room $\mathrm{B}$ to give information about the first task by means of an intercom system.

The subject's task was to answer nine questions from a "test of common sense." Each question had four possible answers, which actually were 
equally right; and for each question the boy was to indicate his answers by pressing one of the four buttons on the teaching machine in front of him. This was supposed to light a signal on the partner's machine in room $\mathrm{C}$ and tell him the subject's answer. At the end of the nine answers, the partner would have to evaluate the subject's performance on the test. The experimenter gave an example, asked whether there were any questions, and the task started.

After completion of the "test," the first experimental manipulation was introduced. For half of the sample, those in the neutral condition, the confederate provided a fairly innocuous evaluation over the intercom, saying the subject "answered the questions like any average guy" and that he "seemed to know what he was talking about." Each of the remaining subjects, those in the insult condition, heard the confederate belittle their answers. The confederate said the subject wouldn't have gotten even the first question right if the experimenter hadn't told him the answer and announced that the subject "sounded kind of stupid" to him, with very little common sense.

The next part of the experiment concerned the film treatments. While the partner was in room $\mathrm{C}$ pretending to work on a questionnaire for the last part of the project, the subject either watched a film (in the two film conditions) or sat alone in room A. The movie scene displayed to twothirds of the subjects was a six-andone-half-minute prize fight from the 1949 movie Champion, in which the protagonist, played by Kirk Douglas, received a severe beating. The scene was introduced by a synopsis supposed to summarize the story up to the fight, supposedly so that the viewer would better understand what was happening. The justified aggression summary portrayed Kirk Douglas as a scoundrel who had frequently exploited the people in his life, while the less justified aggression synopsis depicted him in a rather sympathetic manner.

While the boy was watching the film, the experimenter was supposed to see how the partner was doing on his task in room $\mathrm{C}$. When the film was over, the experimenter returned and told the subject he would participate in the last part of the project. In the no film condition, the test of "common sense" was immediately followed by this last task.

The confederate remained in room $\mathrm{C}$; and the subject was taken into the middle room, $\mathrm{B}$, where the aggression apparatus was hidden behind white sheets.

\section{Aggression Measure}

The aggression apparatus was a modified version of the "Buss machine" 13 frequently used in laboratory research on aggression and essentially is a set of ten switches supposedly permitting the subject to administer shocks of ten different intensities. Upon receipt of a signal ostensibly indicating when his partner had made a "mistake" (the signal light was actually controlled by the confederate following a prearranged schedule), the subject had to shock his partner in the next room but could select the shock intensity ranging from very weak to relatively strong, on the 1-to10 scale. The experimenter pointed out, however, that even the most intense shocks weren't strong enough to injure anyone.

13. A. H. Buss, The Psychology of Aggression (New York: Wiley, 1961). 
TABLE I

Mean Intensity of Shocks Given to Confederate

\section{Film Conditions}

\begin{tabular}{|c|c|c|c|}
\hline & $\begin{array}{l}\text { No } \\
\text { Film }\end{array}$ & $\begin{array}{l}\text { Less Justified } \\
\text { Film Aggression } \\
\end{array}$ & $\begin{array}{c}\text { Justified } \\
\text { Film Aggression } \\
\end{array}$ \\
\hline Neutral Treatment & $\begin{array}{l}5.58 \mathrm{bc} \\
(7)\end{array}$ & $\begin{array}{c}6.40 \mathrm{ab} \\
(7)\end{array}$ & $\begin{array}{l}5.66 \mathrm{abc} \\
(7)\end{array}$ \\
\hline Insult Treatment & $\begin{array}{c}4.28 c \\
(7)\end{array}$ & $\begin{array}{c}6.46 a b \\
(7)\end{array}$ & $\begin{array}{l}7.70 a \\
(8)\end{array}$ \\
\hline
\end{tabular}

Justified

Note: Cells having different subscripts are significantly different, at the .05 level, by Duncan Multiple Range Test.

The numbers in parentheses are the number of cases in each cell.

The other boy was supposedly answering questions given him by the experimenter, with the experimenter signaling to the subject whenever the partner was wrong. Every subject was led to believe his partner had made 10 "mistakes" out of 15 questions, giving each subject 10 opportunities to punish the other boy. The aggression score of concern to us here is the mean intensity of the shocks given to the confederate over the 10 trials.

\section{RESUlts}

\section{Condition Differences}

Even though different experimenters and different confederates were used in the fall and spring sessions, the data from these two periods were combined because of the small number of cases run in each condition in any one session. Analysis of variance of the resulting shock intensity scores yielded only a significant main effect for the film conditions ( $F=3.94,2$ and $39 \mathrm{df}, \mathbf{p}<.05)$, indicating that the subjects seeing the two violent movies were significantly more aggressive toward the confederate than were the boys seeing no film at all. The interaction of insult treatment with film conditions just missed the customary significance level $(F=$ $3.07,2$ and $39 \mathrm{df}, \mathrm{p}=.06$ ). However, since the pattern of means closely resembled the usual pattern obtained with university students, it was likely that the findings were not random; and the differences among the six condition means were tested by means of the Duncan Multiple Range Test. The findings are summarized in Table I.

The table shows, first, that the film conditions did not significantly influence the level of aggression displayed by the subjects receiving the neutral treatment. However, since Hartmann ${ }^{14}$ had obtained a signifi-

14. D. P. Hartmann, "Influence of Symbolically Modeled Instrumental Aggression and Pain Cues on Aggressive Behavior," Journal of Personality and Social Psychology, 11:280-288, 1969. 
cant effect for movie violence in a similar study also employing institutionalized juvenile delinquents, it might be that the present boys were too restrained to reveal the aggression enhancing consequences of the fight scene. This heightened instigation to aggression can be seen, however, in the insulted group; as in the university experiments, the provoked subjects who had watched a "bad" person being beaten subsequently attacked their tormentor more severely than did any other group. These juvenile delinquents evidently regarded the witnessed aggression in this condition as being warranted or "proper" so that their own aggression also seemed justified for the time being. Like the university students, they apparently thought an unfeeling exploiter of others deserved a severe beating.

\section{Correlational Findings}

The shock intensity scores were related to other measures obtained from the youngsters' official records in order to determine whether the laboratory behavior reflected more persistent characteristics. Two shock scores were used, one the mean shock intensity measure found to yield significant effects in the preceding analysis and the other the intensity of the shock delivered by the subject on his first trial. Other research ${ }^{15}$ suggests that even though the score based on 10 "items" is generally more reliable than a single "item" score, the initial shock trial might be less susceptible to conscious control than the later shock behavior. For our exploratory purposes we thought it would be interesting to employ both measures.

15. L. Berkowitz and J. Alioto, "The Meaning of an Observed Event as a Determinant of Its Aggressive Consequences," Journal of Personality and Social Psychology, 1973, in press.
The condition effects were eliminated for this correlational analysis by transforming each subject's scores into $z$ scores, holding the influence of the insult and film conditions constant.

It was found that the laboratory aggressiveness had the strongest associations with three ratings of the boys' behavior in the institution. In arriving at these measures, raters on our staff read the social workers' descriptions of each boy's conduct in the institution and then rated each subject on three seven-point scales ${ }^{16}$ : (1) how likable the boy was to the counselor and how easy it was for the counselor to get along with him, (2) the goodness of the boy's relationships with his peers in the institution, and (3) the quality of his judgment and his ability to fulfill his responsibilities. Even though the case descriptions were rather sparse, the raters showed a surprisingly high degree of agreement in their assessments of the boys. The average intercorrelations among the three raters were all above 7 .

As is shown in Table II, each of these three ratings was either significantly or nearly significantly correlated with the mean intensity of the shocks the boys inflicted on the confederate in the laboratory setting. Moreover, there was an even higher multiple correlation between the laboratory aggressiveness and the best weighted combination of these three ratings, as indicated on Line 4 of the table. All in all, in this study as in the other investigations cited earlier, the youngsters displaying the greatest aggressiveness on the experimental task also tended to be the most hostile boys in the sample in their relationships with their peers and counselors in the institution. One final observa-

16. The scales used in these ratings were developed by James Cowden. 
tion: The last two lines of the table indicate that these ratings of institutional behavior are a better predictor of laboratory aggressiveness than either the boys' socioeconomic status, as indexed by their fathers' occupational level, or their age at first admission to a reformatory, two variables often found to be related to persistent delinquency.

\section{Discussion}

The present results extend the generality of the earlier findings obtained with university students. In this sample as in the university groups, when angry people watch a "bad" person receive a beating, they are subsequently more inclined to attack the "bad" individual in their own lives who had previously insulted them. These comparable results also suggest that the delinquents in our sample had employed the same kind of moral standards as did the university students in evaluating the defeated movie character; in both cases this character was evidently viewed as getting his "just desserts" if he had been depicted as someone who had ruthlessly exploited other people.

Assuming this interpretation of the findings is correct, it would appear that the approbation many delin-

TABLE II

Product-Moment Correlations between Laboratory Measures and Ratings of Behavior in INSTITUTION

\begin{tabular}{|c|c|c|c|}
\hline & \multicolumn{2}{|c|}{ Shock Intensity } & \multirow[b]{2}{*}{$\begin{array}{l}\text { Reliability } \\
\text { of measure }\end{array}$} \\
\hline & $\begin{array}{l}\text { Ist } \\
\text { Tria } 1 \\
\end{array}$ & $\begin{array}{c}\text { Mean, } \\
\text { Al1 Trials } \\
\end{array}$ & \\
\hline Boys' Likeability & .16 & $.29 *$ & .79 \\
\hline Peer Relationships & .16 & $.31 *$ & .84 \\
\hline Quality of Judgment & $.28 *$ & .27 & .70 \\
\hline Best Weighted Combination & $.49 *$ & $.38 * 1$ & $\begin{array}{l}\text { No } \\
\text { Info. }\end{array}$ \\
\hline Father's Occupational Level & .08 & .22 & .83 \\
\hline Age at First Admission & .01 & .15 & .98 \\
\hline
\end{tabular}

Note: Because of missing data, the above analyses are based on 40 of the 44 cases. Positive correlations indicate that less favorable qualities (or lower status) are associated with intense aggressiveness. $\star p<.05$.

${ }^{a}$ Average intercorrelation among the 3 raters. 
quents give to someone who is tough and manipulative ${ }^{17}$ stems from an appreciation of his cleverness rather than from a blanket approval of the injury he has done to others. Very few members of our society think kindly of aggression. ${ }^{18}$ If someone is

17. Shore, supra note 6.

18. M. D. Blumenthal et al, Justifying Violence: Attitudes of American Men (Ann Arbor, Mich.: Institute for Social Research, 1972). to be hurt deliberately, most people feel there ought to be a good reason. Delinquents might differ from other groups in exactly what they regard as a sufficient justification for doing injury to others and/or in how readily they try to define their own aggression as being warranted but, nevertheless, still seem to apply common moral standards in evaluating the propriety of another person's aggression. 